\title{
The Influence of C936T Gene in Wild of the Vascular Endothelial Growth Factor and Biochemical Variants Analysis for Alpha-Fetoprotein in Hepatocellular Carcinoma Patients in Egypt
}

\author{
Khaled El-Khashab AE', Soha Hamdy $\mathbf{M}^{2 *}$, Gamal Tamam $\mathbf{H}^{3}$, Sahar Soliman $\mathbf{M}^{2}$ and Asmaa Rady $\mathrm{AM}^{2}$ \\ ${ }^{1}$ Cardiology Division, Clinical Cardiology Department, Faculty of Medicine, Fayoum, University, Fayum, Egypt \\ ${ }^{2}$ Biochemistry Division, Department of Chemistry, Faculty of Science, Fayum University, Fayum, Egypt \\ ${ }^{3}$ Organic Chemistry Division, Chemistry Department, Faculty of Science, Fayoum University, Fayum, Egypt
}

\begin{abstract}
Hepatocellular carcinoma (HCC) is one of the most frequent malignant tumors. It is important to detect disease and recurrence at its earlier period. The aim of this study was to evaluate the influence of the C936T polymorphism of the VEGF and Alfa feto-Protein (AFP) on Hepatocellular carcinoma (HCC), Hepatitis C Virus (HCV) and control groups. Also, estimation of serum AFP and correlation with other parameters was studied. In this study was included 75 subjects, 25 patients with HCV, 25 patients with confirmed HCC and 25 healthy volunteers were subjected to abdominal ultrasonography, AFP and VEGF were assessed. The statistical analysis will include the Fisher exact test, $T$ test and the multivariate regression, with significance level $\mathrm{P}<0.05$ (AU). The result has showed that Serum level of AFP was significantly higher in $\mathrm{HCC}$ group when compared with control group and There was a nonsignificant increase in serum (AFP) level in the untreated HCV infected group compared to control group and also there was a nonsignificant increase in serum (AFP) activity in the HCC group compared to untreated HCV infected group with a $(P$ value $=0.203)$. the influence of the C936T polymorphism of the VEGF distribution of the studied groups showing that Positive gene have higher incidence of HCV and HCC infection than Negative gene, when compared to control group. Sensitivity and specificity of markers in diagnosis of HCC were $52 \%$ and $40 \%$ respectively for AFP using a cutoff value of $3.39 \mathrm{ng} / \mathrm{ml}$. VEGF may be useful marker for detection of HCC in addition to traditional markers.
\end{abstract}

Keywords: Alfa Feto-Protein (AFP), Hepatocellular Carcinoma (HCC), Hepatitis C Virus (HCV), Vascular Endothelial Growth Factor (VEGF)

\section{Introduction}

The burden of Hepatocellular carcinoma (HCC) has been increasing in Egypt with a doubling in the incidence rate in the past 10 years [1]. Early diagnosis of HCC is of great importance in order to offer the possibility of curative treatment. Surveillance programs have been conducted in many countries to detect HCC at an early stage. Alfa feto-Protein (AFP) and ultrasonography are usually used as diagnostic tools [2]. Most patients with HCV have two diseases, liver cirrhosis and HCC, and complex interactions between the two have major implications for prognosis and treatment choice [3]. However, the biological mechanism for the relationship between these diseases is not clear [4]. HCV is the commonest cause of chronic hepatitis, liver cirrhosis and liver cancer in Egypt, where 12\% to 15\% of the population have HCV antibodies (anti-HCV) [5]. The discovery of genetic factors associated with cancer risk may help lower the stage and improve survival $[6,7]$.

Angiogenesis is an essential process in the development, growth and metastasis of malignant tumors. Vascular endothelial growth factor (VEGF) plays an important role in the angiogenesis. Increased VEGF expression is associated with tumor growth and metastasis [8]. The human VEGF gene is located on chromosome 6 p21.3 and is organized into 8 exons separated by 7 introns. Several polymorphisms have been described in the VEGF gene. Three single-nucleotide polymorphisms $\left(\mathrm{G}+405 \mathrm{C}\right.$ in the $5^{\prime}$-untranslated region, $\mathrm{C}-460 \mathrm{~T}$ in the promoter region, and $\mathrm{C}+936 \mathrm{~T}$ in the $3^{\prime}$-untranslated region) are common and related to VEGF protein production. Different factors designated VEGF-A, VEGF-B, VEGF-C, VEGF-D, VEGF-E, placenta growth factor, and snake venom VEGF (VEGF-F). The receptors for VEGF are located on the surface of endothelial cells. VEGF, which has a mitogenic effect on endothelial cells and increases their migratory capacity [9]. Epigenetic mechanisms play an essential role in normal development and maintenance of physiological functions in humans. Emerging evidence indicates that aberrant epigenetic mechanisms are strongly involved in the genesis and progression of human disorders [10]. Take histone methyltransferase G9a for example, overexpression of this enzyme has been found to be associated with poor prognosis in different types of cancers [11]. Interestingly, previous study has shown that the expression of alpha-fetoprotein was significantly higher in patients with G9a-positive tumors [12]. In mammals, the main function of G9a is depositing of $\mathrm{H} 3 \mathrm{~K} 9 \mathrm{me} 1 / 2$ at the euchromatin loci [13]. In addition, G9a also interacts with DNA methyltransferase and maintains DNA methylation at imprinted loci [14]. Therefore, understanding the patterns of $\mathrm{H} 3 \mathrm{~K} 9 \mathrm{me} 1 / 2$ as well as DNA methylation at alphafetoprotein locus might reveal the potential epigenetic mechanisms that required for the regulation of this gene and shed light for the diagnosis of HCC in humans.

*Corresponding author: Soha M. Hamdy, Biochemistry Division, Department of Chemistry, Faculty of Science, Fayum University, Fayum, Egypt, Tel: 20846380696 E-mail: soha967@yahoo.com

Received April 27, 2017; Accepted July 19, 2017; Published July 21, 2017

Citation: El-Khashab KAE, Hamdy SM, Tamam GH, Soliman SM, Rady AAM (2017) The Influence of C936T Gene in Wild of the Vascular Endothelial Growth Factor and Biochemical Variants Analysis for Alpha-Fetoprotein in Hepatocellular Carcinoma Patients in Egypt. J Cancer Sci Ther 9: 546-553. doi: 10.4172/19485956.1000472

Copyright: (c) 2017 El-Khashab KAE, et al. This is an open-access article distributed under the terms of the Creative Commons Attribution License, which permits unrestricted use, distribution, and reproduction in any medium, provided the original author and source are credited. 
Citation: El-Khashab KAE, Hamdy SM, Tamam GH, Soliman SM, Rady AAM (2017) The Influence of C936T Gene in Wild of the Vascular Endothelial Growth Factor and Biochemical Variants Analysis for Alpha-Fetoprotein in Hepatocellular Carcinoma Patients in Egypt. J Cancer Sci Ther 9: 546-553. doi: 10.4172/1948-5956.1000472

\section{Subjects and Methods}

\section{Study groups}

This study was conducted on seventy five patients attending the Hepatology and Gastroenterology Department, Theodor Bilharz Research Institute (TBRI) either as outpatients for evaluation and assessment or as inpatients to be investigated within the department, in addition to fifteen apparently healthy individuals served as a control group. The Samples of blood were collected from July 2014 up to October 2014. They were divided into three main groups (25 for each): group I: HCV, group II: HCC and group III: healthy controls. Full history and clinical evaluation to assess fitness for further surgical intervention as presence of cirrhosis, status of liver function using child's classification and presence of extra hepatic spread. A history of intraabdominal malignancy, breast or lung cancer or malignant skin caner particularly melanoma raises the possibility of liver metastases. This study was approved by the Ethics Committee of Faculty of Medicine, Fayum University.

\section{Laboratory investigations}

Complete blood count (CBC): This was performed using Sysmex XE-2100 is a haematology automated analyser according to manufacturer instructions [15].

Liver function tests: These were performed using Colorimetric method of serum (AST, ALT, ALP activities, Albumin, Total proteins, Total bilirubin levels) by using Human Gesellschaft für Biochemica und Diagnostica mbH (Germany) laboratories diagnostic kits [16,17].

Qualitative determination of serum (anti-HCV) antibodies: These are done by anti-HCV enzyme linked immunoassay kit (Diasorin S. A., Madrid, Spain) [18]. Alfa Fetoprotein (AFP) in human serum was performed using immunoenzymatic colorimetric method for quantitative determination of AFP concentration in serum or plasma by DiaMetra S.r.l. (Z.I Paciana- ITALY) laboratories diagnostic kits [19].

Evaluate the influence of the C936T Gene in wild of the VEGF on the studied groups was performed by three steps:

Step 1: DNA extraction from whole blood of human was performed using Bio Basic Canada Inc. (EZ-10 Spin Column Genomic DNA Minipreps Kit, Blood) [20].

Step 2: Polymerase chain reaction.

Genomic DNA was isolated from venous blood using a EZ-10 Spin Column Genomic DNA Minipreps Kit, Blood and stored at $4^{\circ} \mathrm{C}$. The primer pair was designed to amplify full sequence of the VEGF gene, VEGF (C936T) primer 1 (5'-AAGGAAGAGGAGACTCTGCGC-3'), primer2 (3'TATGTGGGTGGGTGTGTCTACAG-5'). PCR cycling conditions were $2 \mathrm{~min}$ at $95^{\circ} \mathrm{C}$ followed by 35 cycles with $30 \mathrm{sec}$ at $94^{\circ} \mathrm{C}$, $30 \mathrm{sec}$ at $60^{\circ} \mathrm{C}$ the annealing temperature and the Extension with $2 \mathrm{~min}$ at $72^{\circ} \mathrm{C}[21]$

Step 3: DNA agarose gel electrophoresis was performed using the following:

*AGAROSE D1 LOW EEO (Employed in applications requiring electroendosmosis (EEO) of low value. Cat. No. 8010.11 (Laboratorios Conda S.A.).

* PCR marker: Ethidium bromide.

*50bp DNA ladder RTU (Ready-to-Use), Cat. No. DM012-R500. GeneDirex.

*50x TAE: (stock solution).

\section{Statistical analysis}

Data were collected and analyzed by computer program SPSS "version 17" (The Statistical Package for the Social Science Program), Chicago, USA). All data were expressed as mean \pm SD and percentages. Unpaired t-test was used to compare a quantitative variable between two independent groups in parametric data. Mann Whitney test was used to compare quantitative variables between two independent groups when data were nonparametric (SD $>25 \%$ of mean). Chi square test was used to compare qualitative variables between two independent groups. Correlation between studied parameters was performed by Spearman rank correlation coefficient.

$\mathrm{P}<0.05$ was considered significant. Receiver operating characteristics curves (ROC) were constructed for studied variables, reporting area under the curve (AUC). The ROC analysis was used for the selection of the best diagnostic cut off values, and the related sensitivity and specificity were determined.

\section{Results}

\section{Demographic data and routine investigations}

Table 1 showed that a significant increase in the mean of serum AST, ALT, ALP activities and of creatinine, total bilirubin, direct bilirubin, HCV (ab) levels in HCC group when compared to the control group and there was significant decrease in the mean values of albumin, total protein, Hemoglobin, and Platelets in HCC groups when compared to the control group. Also, $\alpha$-fetoprotein, the mean level was higher in the group of HCC when compared to either the control group or HCV group ( $\mathrm{P}<0.05$ for both). But the mean level of $\alpha$-fetoprotein was decreased in HCC group when compared to the HCV group $(\mathrm{P}<0.203)$.

\section{Influence of the C936T Gene in wild of the VEGF in the studied groups}

Table 2 showed that the number of Positive gene within control, HCV group and the HCC groups were $0 / 25$ (0\%), 3/25 (12\%) and 11/25 (44\%) respectively, showing that Positive gene have higher incidence of HCV and HCC infection than Negative gene, when compared to control group (Figures 1-3) respectively.

6.3 The mean value \pm S.D of the positive and negative gene C936T of the VEGF in all patients (untreated HCV and HCC patients ).

Table 3 showed that the mean value \pm S.D of Alk. phos., GOT, GPT and WBC parameters in Positive gene C936T polymorphism of the VEGF in all patients were $754 \pm 409 \mathrm{ng} / 5 \mu \mathrm{l}, 42 \pm 255 \mathrm{ng} / 5 \mu \mathrm{l}, 190$ $\pm 229 \mathrm{ng} / 5 \mu \mathrm{l}$ and $12 \pm 4.48 \mathrm{ng} / 5 \mu \mathrm{l}$ respectively. There was a highly significant increase in Alk. phos. GOT, GPT and WBC activity in positive gene C936T polymorphism of the VEGF in all patients. $\mathrm{P}<0.05$, $\mathrm{P}<0.001$ respectively. Also there was a nonsignificant decrease in other parameters in the of positive and negative gene C936T polymorphism of the VEGF activity in all patients. P $>0.05$. Also, there was no significant between positive and negative gene C936T polymorphism of the VEGF in all patients. Regarding sex distribution among discovered cases; the proportion of female $7(36.8 \%)$ is slightly more than male proportion 6 (19.4\%) this result in positive gene C936T polymorphism of the VEGF in all patients.

The mean value \pm S.D of the positive and negative gene C936T in wild of the VEGF in HCC patients

Table 4 showed that the mean value \pm S.D of WBC and PLT parameters in Positive gene C936T polymorphism of the VEGF HCC 
Citation: El-Khashab KAE, Hamdy SM, Tamam GH, Soliman SM, Rady AAM (2017) The Influence of C936T Gene in Wild of the Vascular Endothelial Growth Factor and Biochemical Variants Analysis for Alpha-Fetoprotein in Hepatocellular Carcinoma Patients in Egypt. J Cancer Sci Ther 9: 546-553. doi: 10.4172/1948-5956.1000472

\begin{tabular}{|c|c|c|c|}
\hline Variables & Group I & Group II & Group III \\
\hline \multirow{2}{*}{ Mean \pm SD } & Control & (HCV) & (HCC) \\
\hline & $(n=25)$ & $(n=25)$ & $(n=25)$ \\
\hline \multirow{3}{*}{ Age (years) } & \multirow{3}{*}{$53.1 \pm 7.75$} & $55 \pm 11.33$ & $57.7 \pm 7.59$ \\
\hline & & \multirow{2}{*}{$P=\mathrm{NS}$} & ${ }^{*} P=\mathrm{NS}$ \\
\hline & & & ${ }^{* *} P=\mathrm{NS}$ \\
\hline \multirow{2}{*}{$\begin{array}{c}\text { Gender Female } \\
\text { Male }\end{array}$} & 13 & 8 & 11 \\
\hline & 12 & 17 & 14 \\
\hline \multirow{3}{*}{$\operatorname{ALT}(U / L)$} & \multirow{3}{*}{$31 \pm 15$} & $76 \pm 38$ & $164 \pm 188$ \\
\hline & & \multirow{2}{*}{$P=\mathrm{NS}$} & ${ }^{\star} P<0.001$ \\
\hline & & & ${ }^{* *} P<0.05$ \\
\hline \multirow{3}{*}{ AST (U/L) } & \multirow{3}{*}{$38 \pm 29$} & $185 \pm 201$ & $328 \pm 231$ \\
\hline & & \multirow{2}{*}{$P<0.05$} & ${ }^{*} P<0.001$ \\
\hline & & & ${ }^{* *} P<0.05$ \\
\hline \multirow{3}{*}{ ALP (U/L) } & \multirow{3}{*}{$202 \pm 114$} & $283 \pm 171$ & $714 \pm 373$ \\
\hline & & \multirow{2}{*}{$P=\mathrm{NS}$} & ${ }^{*} P<0.001$ \\
\hline & & & ${ }^{* *} P<0.001$ \\
\hline \multirow{3}{*}{ T.Bil (mg/dl) } & \multirow{3}{*}{$1.3 \pm 0.4$} & $1.5 \pm 0.5$ & $1.8 \pm 0.7$ \\
\hline & & \multirow{2}{*}{$P=\mathrm{NS}$} & ${ }^{*} P<0.001$ \\
\hline & & & ${ }^{* *} P=\mathrm{NS}$ \\
\hline \multirow{3}{*}{ D.Bil (mg/dl) } & \multirow{3}{*}{$0.4 \pm 0.3$} & $1.5 \pm 3.9$ & $1.15 \pm 0.6$ \\
\hline & & \multirow{2}{*}{$P=\mathrm{NS}$} & ${ }^{*} P<0.001$ \\
\hline & & & ${ }^{* *} P=\mathrm{NS}$ \\
\hline \multirow{3}{*}{ Albumin (g/dl) } & \multirow{3}{*}{$4.2 \pm 0.5$} & $4.1 \pm 1.1$ & $2.3 \pm 0.4$ \\
\hline & & \multirow{2}{*}{$P=\mathrm{NS}$} & ${ }^{*} P<0.001$ \\
\hline & & & ${ }^{* *} P<0.001$ \\
\hline \multirow{3}{*}{ T. protein (g/dl) } & & $4.8 \pm 1.9$ & $6 \pm 2$ \\
\hline & $8.1 \pm 1.75$ & $P=\mathrm{NS}$ & ${ }^{*} P<0.001$ \\
\hline & & $P=\mathrm{NSS}$ & ${ }^{* *} P<0.05$ \\
\hline & & $1.7 \pm 0.86$ & $2.7 \pm 1.8$ \\
\hline Creatinine (g/dl) & $1.3 \pm 0.24$ & $R$ - & ${ }^{*} P<0.001$ \\
\hline & & $P=\mathrm{NS}$ & ${ }^{* *} P<0.05$ \\
\hline & & $5.44 \pm 1.52$ & $18.59 \pm 9.48$ \\
\hline AFP (ng/ml) & $2.12 \pm 1.54$ & $P-N S$ & ${ }^{*} P<0.05$ \\
\hline & & $P=\mathrm{NS}$ & ${ }^{* *} P=\mathrm{NS}$ \\
\hline & & $1.45 \pm 0.623$ & $1.82 \pm 0.49$ \\
\hline $\mathrm{HCV}(\mathrm{ab})(\mathrm{nm})$ & $0.124 \pm 0.004$ & & ${ }^{*} P<0.001$ \\
\hline & & $P<0.001$ & ${ }^{* *} P<0.05$ \\
\hline & & $10.5 \pm 2.3$ & $9.5 \pm 1.8$ \\
\hline $\mathrm{Hgb}(\mathrm{g} / \mathrm{dl})$ & $13 \pm 2.03$ & $P<0001$ & ${ }^{*} P<0.001$ \\
\hline & & & ${ }^{* *} P=\mathrm{NS}$ \\
\hline & & $7.2 \pm 5$ & $7 \pm 4$ \\
\hline WBC $(10 \times 3 / \mu l)$ & $6 \pm 1.7$ & $P=\mathrm{NS}$ & ${ }^{*} P=\mathrm{NS}$ \\
\hline & & $r=\mathrm{INS}$ & ${ }^{* *} P=\mathrm{NS}$ \\
\hline & & $134 \pm 81$ & $109 \pm 65$ \\
\hline PIt $(10 \times 3 / \mu l)$ & $242 \pm 49$ & $P<0.001$ & $\begin{array}{l}{ }^{*} P<0.001 \\
{ }^{* *} P=\mathrm{NS}\end{array}$ \\
\hline $\begin{array}{l}\mathrm{P} \text { value between group I versus } \\
\mathrm{HCV}=\mathrm{Hepatitis} \mathrm{C} \text { Virus }\end{array}$ & $\begin{array}{l}\text { een group I ver } \\
\text { la } P>0.05 \text { is no }\end{array}$ & $\begin{array}{l}\text { between grou } \\
5 \text { is significant }\end{array}$ & \\
\hline
\end{tabular}

Table 1: Basic laboratory data of the study groups.

\begin{tabular}{|c|c|c|c|c|c|}
\hline \multicolumn{3}{|c|}{ ParametersGroup } & $\begin{array}{c}\text { Control } \\
\text { (25) }\end{array}$ & $\begin{array}{l}\text { HCV } \\
(25)\end{array}$ & $\begin{array}{c}\text { HCC } \\
(25)\end{array}$ \\
\hline \multirow{2}{*}{ VEGF } & positive (+ve) & $\%$ & $(0 \%)$ & $(12 \%)$ & $(44 \%)$ \\
\hline & negative (-ve) & $\%$ & $(100 \%)$ & $(88 \%)$ & $(56 \%)$ \\
\hline
\end{tabular}

Table 2: Comparison of the VEGF Gene in the studied groups. 
Citation: El-Khashab KAE, Hamdy SM, Tamam GH, Soliman SM, Rady AAM (2017) The Influence of C936T Gene in Wild of the Vascular Endothelial Growth Factor and Biochemical Variants Analysis for Alpha-Fetoprotein in Hepatocellular Carcinoma Patients in Egypt. J Cancer Sci Ther 9: 546-553. doi: 10.4172/1948-5956.1000472

patients were $10.9 \pm 2.99 \mathrm{ng} / 5 \mu \mathrm{l}, 75 \pm 37 \mathrm{ng} / 5 \mu \mathrm{l}$, respectively. There was a highly significant increase in WBC and PLT activity in Positive gene C936T polymorphism of the VEGF in HCC patients $\mathrm{P}<0.001$,

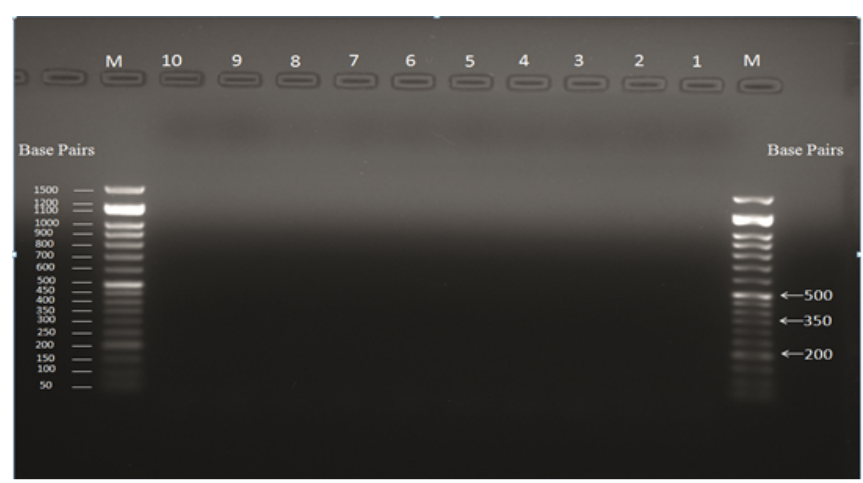

Figure 1: Agarose gel electrophoresis of PCR genotyping in control group M: DNA ladder (50 bp); Lane from (1 to 10) is negative gene (C936T gene polymorphism in VEGF) in control group.

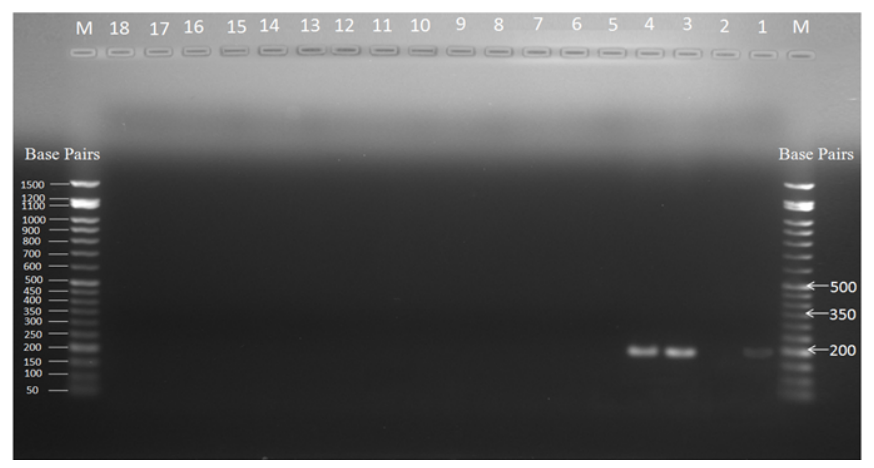

Figure 2: Agarose gel electrophoresis of PCR genotyping in HCV group. M: DNA ladder (50 bp); Lane from (1, 3 and 4) is positive gene (200 bp) (C936T gene polymorphism in VEGF) in HCC group and other lane is negative in the same group.

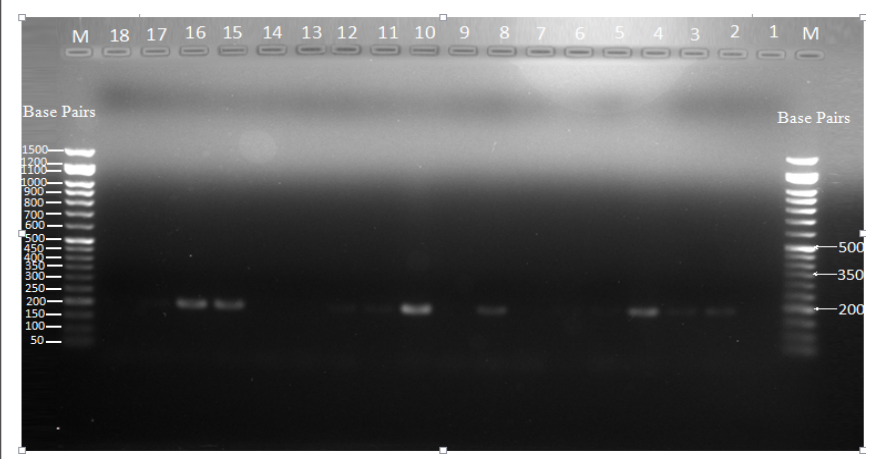

Figure 3: Agarose gel electrophoresis of PCR genotyping in HCC group. M: DNA ladder (50 bp); Lane from (2, 3, 4, 8, 10, 11, 12, 15, 16 and 17) is positive gene (200 bp) in HCV group and other lane is negative in the same group.

\begin{tabular}{|c|c|c|c|}
\hline \multirow{2}{*}{ Parameters } & $\begin{array}{c}\text { Positive gene (+ve) } \\
\text { (ng/5 } \boldsymbol{\mu l})\end{array}$ & $\begin{array}{c}\text { Negativ gene (-ve) } \\
\text { (ng/5 } \boldsymbol{\mu l})\end{array}$ & \multirow{2}{*}{$\boldsymbol{P}$-value } \\
\cline { 2 - 3 } Agean \pm S.D & $57 \pm 5.7$ & $56 \pm 10.7$ & 0.804 \\
\hline T. Protein & $5.5 \pm 1.99$ & $5.36 \pm 2.12$ & 0.822 \\
\hline Alk. Phos. & $754 \pm 409$ & $409 \pm 298$ & $<0.05$ \\
\hline GOT & $421.77 \pm 255.21$ & $199 \pm 186$ & $<0.05$ \\
\hline GPT & $395.23 \pm 229.2$ & $95 \pm 86$ & $<0.05$ \\
\hline Albumin & $2.4 \pm 0.76$ & $3.47 \pm 1.27$ & $>0.05$ \\
\hline Creat & $2.67 \pm 1.7$ & $2 \pm 1.34$ & 0.161 \\
\hline T. Bil & $1.86 \pm 0.755$ & $1.58 \pm 0.54$ & 0.170 \\
\hline D. Bil & $1.16 \pm 0.64$ & $1.37 \pm 1.34$ & 0.822 \\
\hline HCV (ab) & $1.65 \pm 0.55$ & $1.63 \pm 0.60$ & 0.932 \\
\hline AFP & $144 \pm 49$ & $44.76 \pm 26.45$ & 0.312 \\
\hline Hb & $9.95 \pm 1.84$ & $10 \pm 2.2$ & 0.863 \\
\hline WBC & $12 \pm 4.48$ & $5.49 \pm 3.14$ & $<0.001$ \\
\hline PLT & $97 \pm 78.6$ & $130 \pm 71.7$ & 0.174 \\
\hline Female $(\%)$ & $6(54.5 \%)$ & $5(35.7 \%)$ & $>0.05$ \\
\hline Male (\%) & $5(45.5 \%)$ & $9(64.3 \%)$ & \\
\hline
\end{tabular}

Table 3: The mean value \pm S.D of the positive and negative gene in all patients (untreated $\mathrm{HCV}$ and $\mathrm{HCC}$ ).

\begin{tabular}{|c|c|c|c|}
\hline \multirow[t]{2}{*}{ Parameter } & 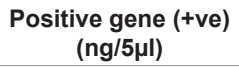 & $\begin{array}{c}\text { Negative gene (-ve) } \\
(\mathrm{ng} / 5 \mu \mathrm{l})\end{array}$ & \multirow[t]{2}{*}{$P$ value } \\
\hline & Mean \pm S.D & Mean \pm S.D & \\
\hline Age & $57 \pm 6.25$ & $58 \pm 8.7$ & 0.744 \\
\hline T. Protein & $5.6 \pm 2.17$ & $6.3 \pm 1.94$ & 0.41 \\
\hline Alk. Phos. & $824 \pm 397$ & $627 \pm 343$ & 0.195 \\
\hline GOT & $394 \pm 228$ & $277 \pm 229$ & 0.219 \\
\hline GPT & $245 \pm 220$ & $128 \pm 127$ & 0.285 \\
\hline Albumin & $2.17 \pm 0.446$ & $2.38 \pm 0.437$ & 0.243 \\
\hline Creatinine & $2.61 \pm 1.82$ & $2.7 \pm 1.78$ & 0.897 \\
\hline T. Bil & $1.87 \pm 0.8$ & $1.7 \pm 0.63$ & 0.626 \\
\hline D. Bil & $1.28 \pm 0.61$ & $1.05 \pm 0.577$ & 0.327 \\
\hline $\mathrm{HCV}(\mathrm{ab})$ & $1.67 \pm 0.59$ & $1.9 \pm 0.37$ & 0.197 \\
\hline AFP & $149 \pm 54$ & $67 \pm 34$ & 0.605 \\
\hline $\mathrm{Hb}$ & $9.6 \pm 1.9$ & $11.3 \pm 2.0$ & 0.327 \\
\hline WBC & $11.4 \pm 5.1$ & $8 \pm 4.3$ & $<0.001$ \\
\hline PLT & $136 \pm 71.8$ & $262 \pm 57$ & $<0.05$ \\
\hline Female (\%) & $6(54.5 \%)$ & $5(35.7 \%)$ & \multirow{2}{*}{$>0.05$} \\
\hline Male (\%) & $5(45.5 \%)$ & $9(64.3 \%)$ & \\
\hline
\end{tabular}

Table 4: The mean value \pm S.D of the positive and negative gene in HCC patients. 
Citation: El-Khashab KAE, Hamdy SM, Tamam GH, Soliman SM, Rady AAM (2017) The Influence of C936T Gene in Wild of the Vascular Endothelial Growth Factor and Biochemical Variants Analysis for Alpha-Fetoprotein in Hepatocellular Carcinoma Patients in Egypt. J Cancer Sci Ther 9: 546-553. doi: 10.4172/1948-5956.1000472

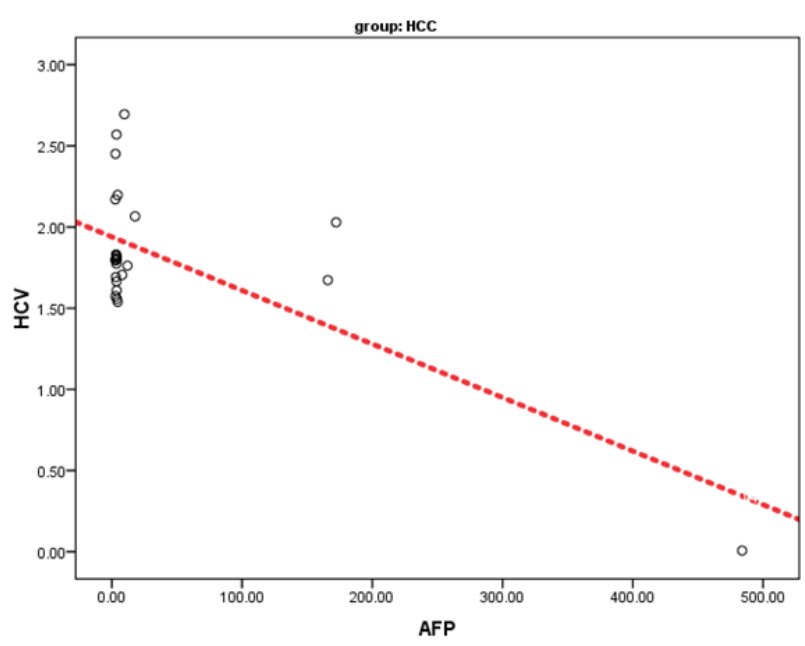

Figure 4: Correlation between serum AFP and HCV $(a b)$ in HCC patients ( $r=$ $0.700, p<0.001)$ (significant correlation).

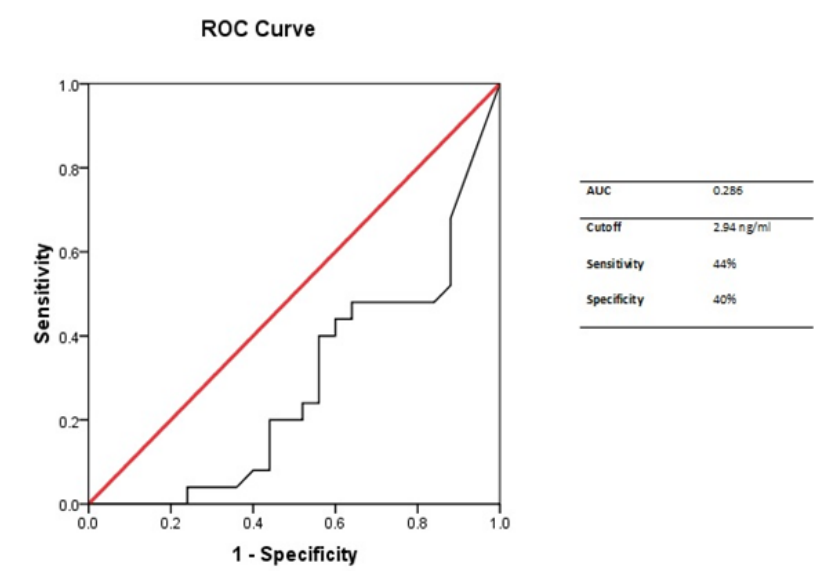

Diagonal segments are produced by ties.

Figure 5: ROC curve of AFP between Control and HCV groups.

$\mathrm{P}<0.05$ respectively. Also there was a nonsignificant decrease in other parameters in the of positive and negative gene C936T polymorphism of the VEGF activity in HCC patients. $\mathrm{P}>0.05$. Also, there was no significant between positive and negative gene C936T polymorphism of the VEGF in HCC patients. Regarding sex distribution among discovered cases; the proportion of female $6(54.5 \%)$ is slightly more than male proportion $5(45.5 \%)$ this result in positive gene C93 6T polymorphism of the VEGF in HCC patients.

\section{Correlations study and ROC curve}

There was a significant negative correlation between AFP and HCV (ab) in HCC group $\mathrm{P}<0.001$. Also, there was a significant correlation between AFP and Age in $\mathrm{HCV}$ group $\mathrm{P}<0.05$ but there were no significant correlation between serum AFP and other biochemical parameters ALT, AST, ALP, T. bilirubin, D. bilirubin, albumin, and T.protein, creatinine, Hb, WBC, PLT. Cut off level, sensitivity, specificity, and the area under the receiver operating characteristic curve (AUROC)

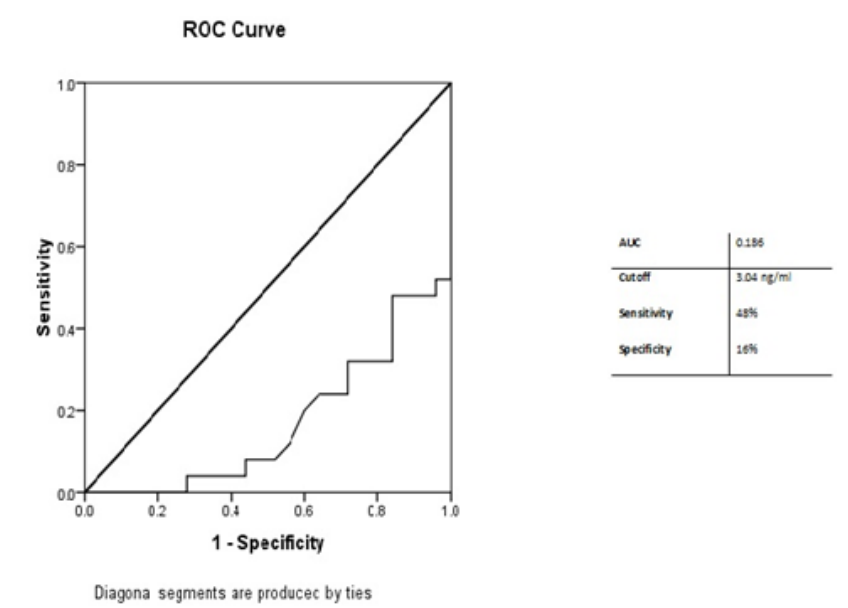

Figure 6: ROC curve of AFP between Control and HCC groups.

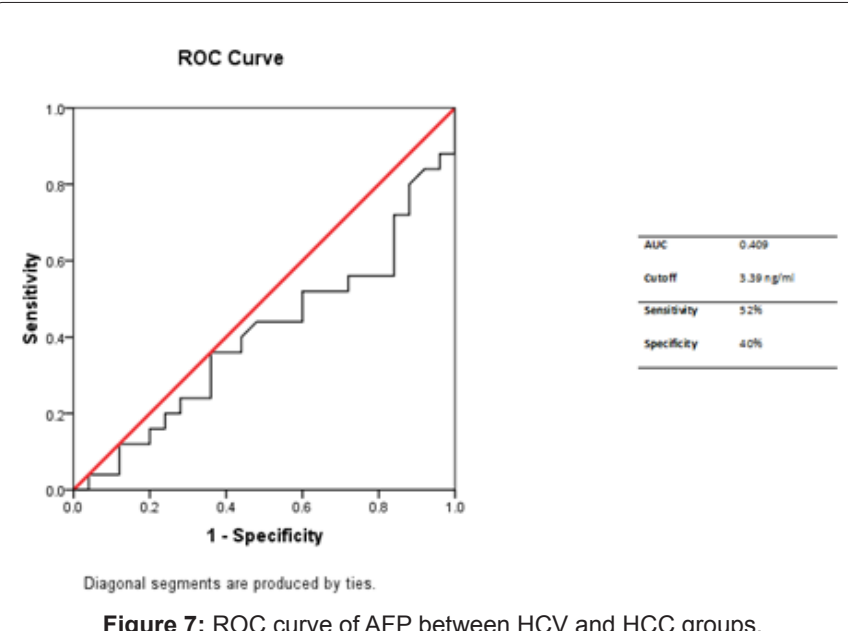

of different tests in the diagnosis of HCC were evaluated and the results tabulated (Figures 4-7).

\section{Discussion}

VEGF has a major effect in regulating angiogenesis, and its expression has been shown to correlate with carcinogenesis [22]. In the present study we found that the influence of the C936T polymorphism of the VEGF distribution of the studied groups that the number of Positive gene within control, HCV group and the HCC groups were 0/25 (0\%), $3 / 25$ (12\%) and 11/25 (44\%) respectively, showing that Positive gene have higher incidence of HCV and HCC infection than Negative gene, when compared to control group, This study agreed with that reported by El-Sherif et al. [23] who found that VEGF was significantly higher among patients than controls and it was more significantly elevated in HCC cases than in those with other groups. The present study showed that in all groups There was a highly significant increase in Alk.phos., GOT, GPT and WBC activity in Positive gene C936T polymorphism of the VEGF in all patients $\mathrm{P}<0.05, \mathrm{P}<0.001$ respecively.Also there was a nonsignificant decrease in other parameters in the of positive and negative gene C936T polymorphism of the VEGF activity in all patients $\mathrm{P}>0.05$. 
Citation: El-Khashab KAE, Hamdy SM, Tamam GH, Soliman SM, Rady AAM (2017) The Influence of C936T Gene in Wild of the Vascular Endothelial Growth Factor and Biochemical Variants Analysis for Alpha-Fetoprotein in Hepatocellular Carcinoma Patients in Egypt. J Cancer Sci Ther 9: 546-553. doi: 10.4172/1948-5956.1000472

In the present study we found that there was a highly significant increase in WBC and PLT activity in Positive gene C936T polymorphism of the VEGF in HCC patients $\mathrm{P}<0.001, \mathrm{P}<0.05$ respectively. Also there was a nonsignificant decrease in other parameters in the of positive and negative gene C936T polymorphism of the VEGF activity in HCC patients $\mathrm{P}>0.05$. Therefore, platelets may transport VEGF to its target cells, restricting the angiogenic activity of circulating VEGF to sites where coagulation takes place, such as a healing wound [24]. This view is supported by the fact that platelet aggregation with cancer cells is commonly observed during the process of angiogenesis and metastasis [25]. There was no significant change between positive and negative gene C936T polymorphism of the VEGF in all patients. Regarding sex distribution among discovered cases; the proportion of female 7 (36.8\%) is slightly more than male proportion $6(19.4 \%)$ this result in positive gene C936T polymorphism of the VEGF in all patients. but, there was no significant between positive and negative gene C936T polymorphism of the VEGF in HCC patients. Regarding sex distribution among discovered cases; the proportion of female 6 (54.5\%) is slightly more than male proportion 5 (45.5\%) this result in positive gene C936T polymorphism of the VEGF in HCC patients. In the present study we found that males have higher liver cancer rates than females ranges in HCV and HCC group about $68 \%$ and $56 \%$ for males in both groups respectively. That finding was in agreement with that reported by Hagymási and Tulassay, [26]. In addition, we found that the incidence of HCV and HCC is higher in the older patients in comparison to the control and this difference was significant when compared to control. That finding was in agreement with that reported by Velazquez et al. [27] who stated that a prospective Spanish analysis of risk factors for HCC found a 4-fold greater risk for developing HCC in patients older than 54 years, while El-Serag and Mason [28] found that the incidence of HCC increases in older age was associated with a higher risk, but the incidence among younger persons also rose progressively. This study also agrees with that reported by Mohamed et al. [29]. Arrieta et al. [30] found a greater proportion of men and a greater mean age for patients with HCC.

In the present study we observed significant increase in both serum ALT and AST in the HCC group compared to control group these results agree with the results obtained by Vincent [31] who reported that viral hepatitis was encountered with dramatic increase of liver enzymes and different degrees of hepatic inflammation as well as fibrosis. The present study showed that there was a highly significant increase in serum ALP activity in the HCC group when compared to control group and untreated HCV infected group $\mathrm{P}<0.001$, but There was a non significant increase in serum ALP activity in the untreated $\mathrm{HCV}$ infected group when compared to control group $\mathrm{P}=0.249$. This was in agreement with that reported by Sleisenger and Fordtran [32] and Morcos et al. [1] who found that the conventional tests of hepatic function don't distinguish hepatocellular carcinoma from other hepatic masses or from cirrhosis. In this study there is a significant increase in serum total bilirubin in the HCC groups compared to control group, but showing non significantly variations between HCC group and HCV group. This result agree with the results reported by Wahib et al. [33], while disagree with Tong et al. [34] who found that HCC patients had higher values of bilirubin, alkaline phosphatase, aspartate aminotransferase and, alanine aminotransferase than those of chronic carriers.

The present study suggested there was a highly significant decrease in serum albumin and T.Protein activity in the HCC group compared to control. but showing nonsignificant decrease in serum albumin activity in the untreated HCV infected group when compared to control group, this result agree with the result obtained by Shaker et al. [35] who reported that plasma Albumin level showed a significant decrease as compared to normal control group. In the present study there was a significant decrease in serum T. Protein level in the untreated HCV infected group when compared to control group, this result agree with that showed by Mahdy et al. [36].

In the present study there was a highly significant increase in serum creatinine activity in the HCC group compared to control and untreated $\mathrm{HCV}$ infected group $\mathrm{P}<0.001, \mathrm{P}=0.004$ respectively, this result disagree with Nguyen et al. [37] and Zakhary et al. [38] who reported that the level of creatinine non significantly decrease in HCC group compared to other studied groups.

In the present study there was a highly significant decrease in Hemoglobin and Platelets activity in the HCC group and untreated $\mathrm{HCV}$ infected group when compared to control group, and also, there was a nonsignificant increase in white blood cells (WBC) activity in the HCC group and untreated HCV infected group when compared to control group. this result agree with El-Sherif et al. [23] and Noritake et al. [39] who reported that there was a highly significant increase in Hemoglobin and Platelets counts activity in the HCC group when compared to other studied groups $\mathrm{P}<0.001$.

In the present study there was a highly significant increase in serum (HCV) antibodies in the HCC group and untreated HCV infected group when compared to control group, and also, there was a highly significant increase in serum (HCV) antibodies activity in the HCC group when compared to untreated HCV infected group. this result agree with Baghdady et al. [2] who reported that In Egypt, HCV is the main risk factor for HCC, wherein $71 \%$ of the HCC cases are positive for anti-HCV antibodies.

In the present study a highly significant increase in serum (AFP) level in the HCC group compared to control group. This result agree with that stated by Baghdady et al. [2] who declared that significantly elevated serum levels of alpha fetoprotein (AFP) in patients with HCC compared to control participants as detected by enzyme-linked immunosorbent assay, and also, There was a non-significant increase in serum (AFP) level in the untreated HCV infected group compared to control group.

In our study there was nonsignificant correlation between serum AFP and other biochemical parameters ALT, AST, ALP, T. bilirubin, D. bilirubin, albumin, and T. protein, creatinine, Hb, WBC, PLT in HCC group, This result agree with those supported by Nguyen et al. [37] Who found that no significant correlation was found between serum AFP levels and gender, various tumor factors. Also, there was a significant correlation between AFP and Age in HCV group $\mathrm{P}<0.05$, this result agree with Bruce et al. [40] stated that elevated AFP level was significantly correlation associated with increasing age in HCV group. In the present study we found that There was a significant negative correlation between AFP and HCV (ab) in HCC group $\mathrm{P}<0.001$, this result agree with those supported by Zainal et al. [41] who found that There is a growing number of evidence that AFP levels are significantly raised in anti-HCV- positive in HCC group. In our study when using receiving operator characterizing curve (ROC curve) to reach the value of the best sensitivity and specificity for AFP, it was found that at a value of $3.39 \mathrm{ng} / \mathrm{ml}$ (the best cut off) yields, the sensitivity was $52 \%$ and the specificity was $40 \%$. Zakhary et al. [38] reported a cutoff of as a diagnostic cutoff. According to our results, at a cut-off $28 \mathrm{ng} / \mathrm{dl}$ shows the sensitivity was $(73.3 \%)$ and specificity was (75\%). This result was in 
Citation: El-Khashab KAE, Hamdy SM, Tamam GH, Soliman SM, Rady AAM (2017) The Influence of C936T Gene in Wild of the Vascular Endothelial Growth Factor and Biochemical Variants Analysis for Alpha-Fetoprotein in Hepatocellular Carcinoma Patients in Egypt. J Cancer Sci Ther 9: 546-553. doi: 10.4172/1948-5956.1000472

accordance to chen et al. [42] reported a cutoff of as a diagnostic cutoff. According to our results, at a cut-off $15.6 \mathrm{ug} / \mathrm{L}$ shows the sensitivity was $(34.3 \%)$ and specificity was $(83.6 \%)$. Concluding that reducing the cut-off means that more HCCs would be identified, but at the cost of a progressive increase in the false positive rate.

\section{Conclusion}

In conclusion, it has been found that the presence of gene C936T is strongly correlated with HCC cases, and Alpha fetoprotein (AFP) is serological marker specific for HCV group with HCC.

\section{Acknowledgements}

I would first like to thank my thesis advisor Staff members and my colleagues at the chemistry department in the faculty of science at Fayoum University. The door to Prof. El-khashab office was always open whenever I ran into a trouble spot or had a question about my research or writing. Prof. Dr. Soha Mohamed Hamdy consistently allowed this paper to be my own work, but steered me in the right the direction whenever he thought I needed it.

\section{References}

1. Morcos NYS, Khafagi EZI, Mogawer MS, Ali MM, Abdel-Halim AH, et al. (2012) Evaluation of biomarkers for the detection of hepatocellular carcinoma in patients with hepatitis C virus. J Exp Integr Med 2: 321-329.

2. Baghdady I, Fouad F, Sayed M, Shoaib A, Salah Y, et al. (2014) Serum markers for the early detection of hepatocellular carcinoma in patients with chronic viral hepatitis C infection. Menoufia Med J 27: 544-550.

3. Metwaly HA, Al-Gayyar MM, Eletreby S, Ebrahim MA and El-Shishtawy MM (2012) Relevance of serum levels of interleukin- 6 and syndecan-1 in patients with hepatocellular carcinoma. Sci Pharm 80: 179-88.

4. Huang T, Wang J, Cai YD, Yu H, Chou KC (2012) Hepatitis C virus network based classification of hepatocellular cirrhosis and carcinoma. PLoS One 7: e34460.

5. Guerra J, Garenne M, Mohamed MK, Fontanet A (2012) HCV burden of infection in Egypt: Results from a nationwide survey. J Viral Hepat 19: 560-567.

6. Bosch LJ, Carvalho B, Fijneman RJ, Jimenez CR (2011) Molecular tests for colorectal cancer screening. Clin Colorectal Cancer 10: 8-23.

7. Jelovac D, Armstrong DK (2011) Recent progress in the diagnosis and treatment of ovarian cancer. CA Cancer J Clin 61: 183-203.

8. Liu XL, Yang QF, Kong BH (2013) Vascular endothelial growth factor $+936 \mathrm{C} / \mathrm{T}$ polymorphism and cancer risk in Asians: a meta-analysis. Genet Mol Res 12: 1924-1933.

9. Şamlı H, Demir BÇ, Özgöz A, Atalay MA, Uncu G (2012) Vascular endothelial growth factor gene $1154 \mathrm{G} / \mathrm{A}, 2578 \mathrm{C} / \mathrm{A}, 460 \mathrm{C} / \mathrm{T}, 936 \mathrm{C} / \mathrm{T}$ polymorphisms and association with recurrent pregnancy losses. Genet Mol Res 11: 4739-4745.

10. Shikhar S, Theresa KK, Peter AJ (2010) Epigenetics in cancer. Carcinogenesis 31: $27-36$.

11. Francesco C, Karolina W, Frank G, Jason SL (2015) Functional role of G9a histone methyltransferase in cancer. Front Immunol 6: 487

12. Kai B, Yi C, Chao H, Jianwei C, Xiaojin Z, et al. (2016) Association of histone methyltransferase G9a and overall survival after liver resection of patients with hepatocellular carcinoma with a median observation of 40 months. Medicine 95: 2493.

13. Tachibana M, Nozaki M, Takeda N, Shinkai Y (2008) Functional dynamics of H3K9 methylation during meiotic prophase progression. EMBO J 27: 2681 2690.

14. Zhang T, Termanis A, Özkan B, Bao XX, Culley J, et al. (2016) G9a/GLP Complex Maintains Imprinted DNA Methylation in Embryonic Stem Cells. Cell Reports 15: 77-85.

15. Anthea P, Christopher JK (2009) Estimated platelet and differential leucocyte counts by microscopy, Sysmex XE-2100 and Cella Vision TM DM96. N Z J Med Lab Sci 63: 3-10.

16. Schumann G, Klauke R (2003) New IFCC reference procedures for the determination of catalytic activity concentrations of five enzymes in serum:
Preliminary upper reference limits obtained in hospitalized subjects. Clin Chim Acta 327: 69.

17. Schumann G, Bonora R, Ceriotti F, Férard G, Ferrero CA, et al. (2002) IFCC primary reference procedures for the measurment of catalytic activity concentrations of enzymes at 37 degrees $\mathrm{C}$. International Federation of Clinical Chemistry and Laboratory Medicine. Part (5) Reference procedure for the measurment of catalytic concentration of aspartate aminotransferase. Clin Chem Lab Med 40: 725.

18. Choo QL, Weiner AJ (1990) Hepatitis C Virus: The major causative agent of viral non-A, non-B hepatitis. Br Med Bull 46: 423-441.

19. Jacobsen G K (1983) Alpha-Fetoprotein (AFP) and Human Chorionic Gonadotropin (HCG) in testicular germ cell tumors. Acta Path Microb Immun Scand 91: 183

20. Souvik G, Rajendra BM, Senthil KN (2013) A Simple Method of Genomic DNA Extraction from Human Samples for PCR-RFLP Analysis. J Biomol Tech 24 224-231.

21. Zijlstra C, Donkers VD, Fagette M (2000) Identification of Meloidogyn incognita, M. Javanica and M. arenaria using sequence characterised amplified region (SCAR) based PCR assays. Nematology 2: 847-853.

22. Grizzi F, Franceschini B, Hamrick C, Frezza EE, Cobos E, et al. (2007) Usefulness of cancer-testis antigens as biomarkers for the diagnosis and treatment of hepatocellular carcinoma. J Transl Med 5: 3 .

23. El-Sherif WT, Makhlouf NA, El-Gendi SS, Hassan HI, Herdan OM (2012) Evaluation of transforming growth factor alpha and vascular endothelial growth factor in diagnosis of hepatocellular carcinoma. EJI 19: 53-65.

24. Maloney JP, Silliman CC, Ambruso DR, Wang J, Tuder RM, et al. (1995) In vitro release of vascular endothelial growth factor during platelet aggregation. Am J Physiol 275: 1054-1061.

25. Trikha M, Nakada MT (2002) Platelets and cancer: Implications for antiangiogenic therapy. Semin Thromb Hemos 28: 39-44.

26. Hagymáasi K, Tulassay Z (2008) Epidemology, risk factors and molecular pathogenesis of primary liver cancer. Orv Hetil 149: 541.

27. Velazquez RF, Rodriguez M, Navascues CA, Linares A, Perez R, et al. (2003) Prospective analysis of risk factors for hepatocellular carcinoma in patients with liver cirrhosis. Hepatology 37: 520.

28. El-Serag HB, Mason AC (1999) Rising incidence of hepatocellular carcinoma in the United States. N Engl J Med 340: 745

29. Mohamed N, El-Zawahry H, Mokbtar N, Faisal S, Gad El-Mawla N (2000) Review of epidemiologic and clinicopathologic features of 403 hepatocelluar carcinoma (HCC) patients. J Egypt Natl Canc Inst 12: 87

30. Arrieta O, Cacho B, Morales ED, Ruelas VA, Flores ED, et al. (2007) The progressive elevation of alpha fetoprotein for the diagnosis of hepatocellular carcinoma in patients with liver cirrhosis. BMC Cancer 7: 28.

31. Vincent B (2004) Physician updates: Liver function testes. Can Liver Found 2: $1-3$

32. Sleisenger MF, Fordtran BF (1998) Hepatic tumors and cysts. Gastrointestinal and liver disease (6th edn) 2: 1371

33. Wahib AA, El-Nasr MSS, Mangoud AM, El-Shazly AM, Morsy ATA (2005) The liver funcion profile in PCR-RNA Egyptian HCV patients and normal controls. Egypt Soc Parasitol 35: 451.

34. Tong MJ, Blatt LM, Kao JH, Cheng JT, Corey WG (2007) Basal core promote T1762/A1764 and precore A1896 gene mutations in hepatitis B surface antigen-positive hepatocellular carcinoma: A comparison with chronic carriers. Liver Int 27: 1356

35. Shaker OG, Sadik NA, EIDessouki A (2012) Single-nucleotide polymorphism in the promoter region of the osteopontin gene at nucleotide 443 as a marke predicting the efficacy of pegylated interferon/ ribavirin-therapy in Egyptians patients with chronic hepatitis C. Human Immunology 73: 1039-1045

36. Mahdy KA, Ahmed HH, Mannaa F, Abdel SA (2007) Clinical benefits of biochemical markers of bone turnover in Egyptian children with chronic liver diseases. World J Gastroenterol 13: 785-790.

37. Nguyen MH, Garcia RT, Simpson PW, Wright TL, Keeffe EB (2002) Racial differences in effectiveness of alpha-fetoprotein for diagnosis of hepatocellular carcinoma in hepatitis $\mathrm{C}$ virus cirrhosis. Hepatology 36: 410-7. 
Citation: El-Khashab KAE, Hamdy SM, Tamam GH, Soliman SM, Rady AAM (2017) The Influence of C936T Gene in Wild of the Vascular Endothelial Growth Factor and Biochemical Variants Analysis for Alpha-Fetoprotein in Hepatocellular Carcinoma Patients in Egypt. J Cancer Sci Ther 9: 546-553. doi: 10.4172/1948-5956.1000472

38. Zakhary NI, Khodeer SM, Shafik HE, Abdel MCA (2013) Impact of PIVKA-II in diagnosis of hepatocellular carcinoma: JAR 4: 539-546.

39. Noritake H, Kobayashi Y, Ooba Y, Kitsugi K, Shimoyama S, et al. (2014) Improved serum alpha-fetoprotein levels after iron reduction therapy in HCV patients. ISRN Hepatology 10: 1155-1162.

40. Bruce MG, Bruden D, McMahon BJ, Christensen C, Homan C, et al. (2008) Clinical significance of elevated alpha-fetoprotein in Alaskan Native patients with chronic hepatitis C. J Viral Hepat 15: 179-187.
41. Zainal IG, Safa AA, Obead WK (2013) Biochemical Parameters in relation to serum alpha fetoprotein \& leptin levels in iraqi patients with chronic liver diseases. ISSN 3: 2250-2480.

42. Chen CH, Lin ST, Kuo CL, Nien CK (2008) Clinical significance of elevated alphafetoprotein (AFP) in chronic hepatitis $\mathrm{C}$ without hepatocellular carcinoma. Hepatogastroenterol 55: 1423-1427. 